\title{
A Reversible Single-Crystal to Single-Crystal Thermal Phase Transformation of 3-(2-Bromo-4-(1-methylethyl)phenyl)-1,1-dimethyl urea
}

\author{
Benson M. Kariuki ${ }^{1, *}$ and Gamal A. El-Hiti ${ }^{2, *}$ \\ 1 School of Chemistry, Cardiff University, Main Building, Park Place, Cardiff CF10 3AT, UK \\ 2 Cornea Research Chair, Department of Optometry, College of Applied Medical Sciences, \\ King Saud University, P.O. Box 10219, Riyadh 11433, Saudi Arabia \\ * Correspondence: kariukib@cardiff.ac.uk (B.M.K.); gelhiti@ksu.edu.sa (G.A.E.-H.); \\ Tel.: +966-11469-3778 (G.A.E.-H.); Fax: +966-11469-3536 (G.A.E.-H.)
}

Academic Editors: Alberto Girlando and Anna Painelli

Received: 13 February 2017; Accepted: 1 March 2017; Published: 4 March 2017

\begin{abstract}
Bromo-4-(1-methylethyl)phenyl)-1,1-dimethylurea was synthesized and structurally characterized at $296 \mathrm{~K}, 200 \mathrm{~K}$ and $140 \mathrm{~K}$. A reversible thermal phase transformation was observed at $170-180 \mathrm{~K}$. On cooling, the structure transforms from a monoclinic to a triclinic crystal system. The isopropyl group is disordered above the phase transition temperature but is ordered below the transition temperature.
\end{abstract}

Keywords: crystal-to-crystal; 1,1-dimethylurea; reversible; phase transition; thermal

\section{Introduction}

Urea-containing compounds are established as precursors for several biologically active agents [1-4]. Various efficient procedures have been used for the synthesis of ureas [5-14]. The most recent examples involve reactions of primary amines with $S, S$-dimethyl dithiocarbonate in water followed by reactions with secondary amines [15]; reactions of aromatic amines with secondary amines in the presence of carbon monoxide, sulfur and oxygen in dimethylformamide [16]; and reactions of benzylamine with secondary amines in the presence of a ruthenium catalyst [17]. Other synthetic methods involve the catalytic reaction of carboxylic acids with hydroxylamine hydrochloride followed by reaction with primary amines [18]; conversion of aryl chlorides to the corresponding isocyanates using a palladium catalyst followed by reaction with secondary amines [19]; and conversion of isonitriles to the corresponding isocyanates using dimethyl sulfoxide followed by reaction with tert-butylamine [20]. The reaction of aromatic ureas with a lithium reagent followed by electrophiles is one of the most common methods used to produce substituted derivatives [21-25].

Polymorphic phase transformation is an area of continued research interest [26-35]. The transformation process is an indication of the fine balance in the interactions within the crystal that can be tipped by a relatively small change in conditions [36,37]. In most cases, such transformations proceed with loss of single-crystal integrity, such that a single crystal of the starting solid phase transforms into a polycrystalline sample of the product. Where the structural reorganization involved is small, transformation of a single crystal of the starting material may produce a single crystal of the product phase. Additionally, the process may be reversible but this is rare in organic crystals [30-35]. Enantiotropic behavior has been observed unsurprisingly between forms with very similar unit cell parameters [31,32], but transformation more commonly involves larger shifts in the parameters [33-35]. Polymorphism and polymorphic phase transformations are difficult to predict and are often discovered fortuitously [26]. 
In the current paper, we investigated the synthesis, characterization and reversible single-crystal to single-crystal thermal phase transformation of 3-(2-bromo-4-(1-methylethyl)phenyl)-1,1-dimethylurea.

\section{Results and Discussion}

Phase transformation: In the process of characterization of 3-(2-bromo-4-(1-methylethyl)phenyl) -1,1-dimethylurea following synthesis, the crystal structure was determined initially at $296 \mathrm{~K}$. The structure, $\mathbf{1}_{\mathrm{HT}}$ (Table 1), is monoclinic, $\mathrm{P} 2_{1} / \mathrm{c}$ (with unit cell parameters $a=12.117(2) \AA$, $b=10.0335(10) \AA, c=12.816(2) \AA, \beta=117.82(2)^{\circ}$, volume = 1377.9(5) $\left.\AA^{3}\right)$. Data collection performed at $140 \mathrm{~K}$ in an attempt to improve the quality of the refined structure revealed a different structure (2), indicating that a phase transition had occurred on cooling. Structure 2 is triclinic, P $\overline{1}$, with unit cell parameters $a=11.8916(7) \AA, b=9.9293(6) \AA, c=12.4631(7) \AA, \alpha=92.720(5)^{\circ}, \beta=116.190(5)^{\circ}$, $\gamma=81.000(5)^{\circ}$, volume $=1303.86(14) \AA^{3}$. (This unit cell has been used for ease of comparison with the monoclinic structure 1. The reduced cell is 9.9290(6) $\AA$, 11.8920(7) $\AA$, 12.4630(7) $\AA, 63.810(5)^{\circ}$, $\left.87.280(5)^{\circ}, 81.000(5)^{\circ}\right)$. The matrix for the transformation from 2 to $\mathbf{1}$ is $(1.0072,-0.189,-0.0073$, $0,1.0088,0,-0.0149,0.063,1.0164)$.

Table 1. Experimental and structure refinement data.

\begin{tabular}{|c|c|c|c|}
\hline Identification Code & $\mathbf{1}_{\mathrm{HT}}$ & $\mathbf{1}_{\mathrm{LT}}$ & 2 \\
\hline Empirical formula & $\mathrm{C}_{12} \mathrm{H}_{17} \mathrm{BrN}_{2} \mathrm{O}$ & $\mathrm{C}_{12} \mathrm{H}_{17} \mathrm{BrN}_{2} \mathrm{O}$ & $\mathrm{C}_{12} \mathrm{H}_{17} \mathrm{BrN}_{2} \mathrm{O}$ \\
\hline Formula weight & 285.18 & 285.18 & 285.18 \\
\hline Temperature (K) & $296(2)$ & $200(2)$ & $140(2)$ \\
\hline Wavelength $(\AA)$ & 0.71073 & 0.71073 & 0.71073 \\
\hline Crystal system & Monoclinic & Monoclinic & Triclinic \\
\hline Space group & $\mathrm{P} 2{ }_{1} / \mathrm{c}$ & $\mathrm{P} 2{ }_{1} / \mathrm{c}$ & $\mathrm{P} \overline{1}$ \\
\hline$a(\AA)$ & $12.117(2)$ & $11.8696(12)$ & 11.8916 \\
\hline$b(\AA)$ & $10.0335(10)$ & $10.0171(7)$ & $9.9293(6)$ \\
\hline$c(\AA)$ & $12.816(2)$ & $12.7306(12)$ & $12.4631(7)$ \\
\hline$\alpha\left(^{\circ}\right)$ & 90 & 90 & $92.720(5)$ \\
\hline$\beta\left(^{\circ}\right)$ & $117.82(2)$ & 117.199(13) & $116.190(5)$ \\
\hline$\gamma\left({ }^{\circ}\right)$ & 90 & 90 & $81.000(5)$ \\
\hline Volume $\left(\AA^{3}\right)$ & $1377.9(5)$ & $1346.3(3)$ & $1303.86(14)$ \\
\hline Z & 4 & 4 & 4 \\
\hline$\sigma_{\mathrm{cal}}\left(\mathrm{Mg} / \mathrm{m}^{3}\right)$ & 1.375 & 1.407 & 1.453 \\
\hline$\mu\left(\mathrm{mm}^{-1}\right)$ & 2.967 & 3.037 & 3.135 \\
\hline$F(000)$ & 584 & 584 & 584 \\
\hline Crystal size $\left(\mathrm{mm}^{3}\right)$ & $0.272 \times 0.177 \times 0.122$ & $0.309 \times 0.170 \times 0.106$ & $0.301 \times 0.209 \times 0.099$ \\
\hline Reflections collected & 4752 & 7310 & 11649 \\
\hline Independent reflections & 2718 & 3229 & 11030 \\
\hline$R($ int $)$ & 0.0622 & 0.0284 & 0.0751 \\
\hline Data/restraints/parameters & $2718 / 109 / 166$ & $3229 / 110 / 170$ & $11,649 / 0 / 297$ \\
\hline Goodness-of-fit on $F^{2}$ & 0.813 & 1.036 & 0.913 \\
\hline$R 1[I>2 \sigma(I)]$ & 0.0614 & 0.0673 & 0.0446 \\
\hline wR2 & 0.1619 & 0.1644 & 0.1029 \\
\hline$R 1$ (all data) & 0.1744 & 0.1117 & 0.0850 \\
\hline wR2 & 0.1827 & 0.1961 & 0.1081 \\
\hline
\end{tabular}

The transformation occurs in a single-crystal to single-crystal manner, so it was possible to determine the unit cell parameters as a function of temperature. A plot of the cell parameters recorded for a single crystal shows a discontinuity in the 170-180 K temperature range (Figure 1). Notably, the transformation occurs reversibly. Thus, the monoclinic structure $\left(\mathbf{1}_{\mathbf{L T}}\right)$ discussed below was determined after cooling a crystal past the transition temperature to $150 \mathrm{~K}$, before warming it again to $200 \mathrm{~K}$. 


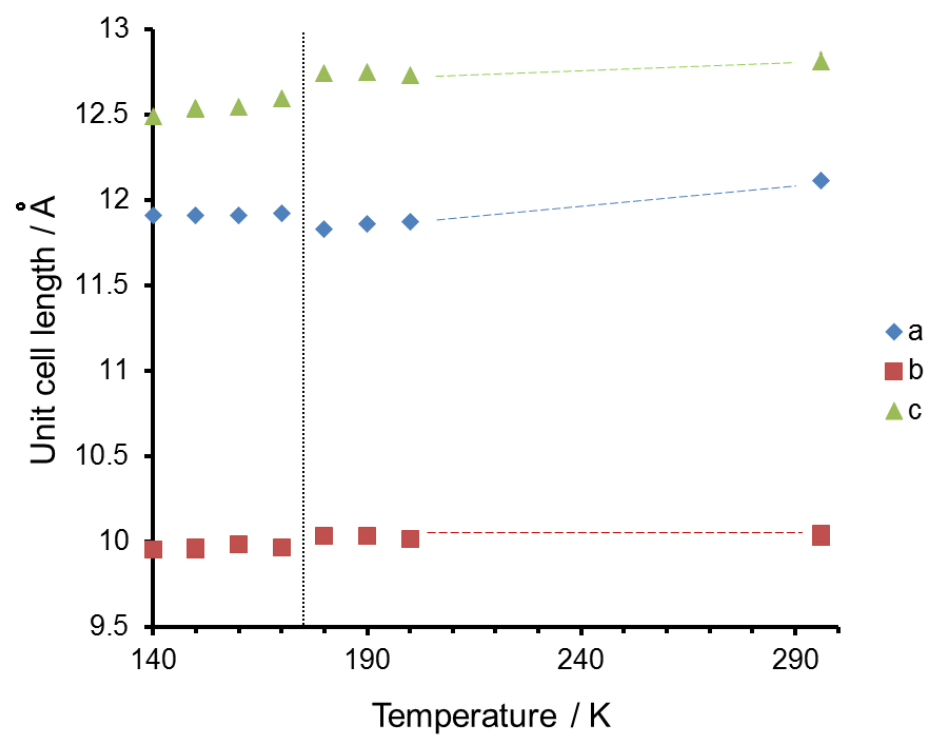

Figure 1. A plot of the unit cell parameters as a function of temperature. The dotted vertical line indicates the phase transition point.

Monoclinic structure: The asymmetric unit of $\mathbf{1}_{\mathrm{LT}}$ consists of one molecule of 3-(2-bromo-4(1-methylethyl)phenyl)-1,1-dimethylurea (Figure 2a). In the molecule, the angle between the planes through the bromophenyl and dimethylurea groups is $59.24(16)^{\circ}$. The isopropyl group is disordered with refined occupancies of $0.725(16)$ and $0.275(16)$ for the two components. The most acute torsion angles for the isopropyl group are $\mathrm{C} 5-\mathrm{C} 4-\mathrm{C} 7-\mathrm{C} 9=-46.3(11)^{\circ}$ and $\mathrm{C} 3-\mathrm{C} 4-\mathrm{C} 7 \mathrm{~A}-\mathrm{C} 8 \mathrm{~A}=-61.6(11)^{\circ}$ for the major and minor components, respectively. In the structure (Figure $2 \mathrm{~b}$ ), chains of molecules are formed along [010] by $\mathrm{N}-\mathrm{H} . . . \mathrm{O}$ hydrogen bonds (with the geometry $\mathrm{N} 1-\mathrm{H} 1 \ldots \mathrm{O} 1=143.8^{\circ}, \mathrm{N} 1 \ldots \mathrm{O} 1=$ 2.869(4) ̊).

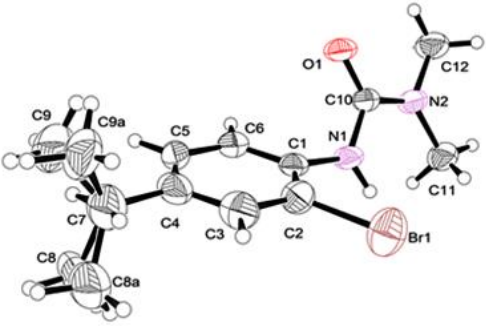

(a)

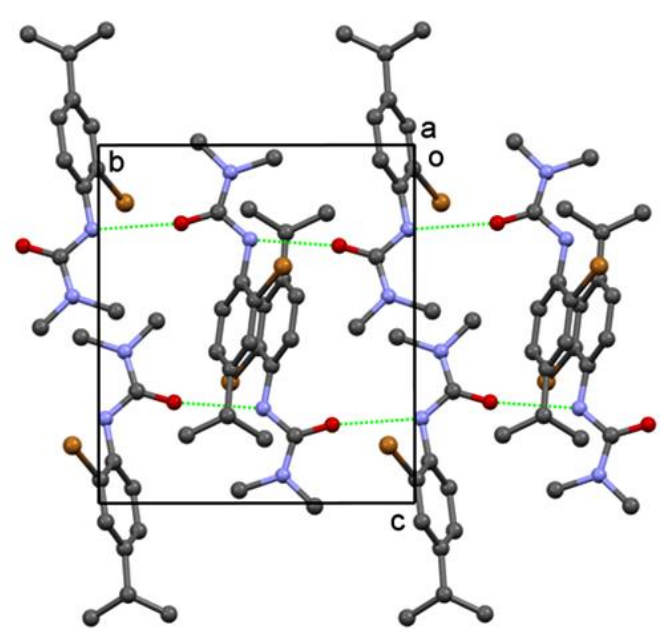

(b)

Figure 2. (a) An ortep representation of the asymmetric unit of $\mathbf{1}_{\mathbf{L T}}$ showing the disordered isopropyl group; (b) Crystal packing viewed down the $a$ axis with hydrogen atoms and one disorder component omitted for clarity. Hydrogen bonds are shown as dashed lines.

Triclinic structure: Structure $\mathbf{2}$ has two independent molecules in the asymmetric unit (Figure 3a). The angles between the planes through the bromobenzene and dimethylurea groups are $69.25(9)^{\circ}$ and $49.51(11)^{\circ}$ for the two molecules. It is notable that the average of these values for the interplanar angles 
is the same as that for the single independent molecule in $\mathbf{1}_{\mathbf{L T}}$. Unlike in $\mathbf{1}_{\mathbf{L T}}$, the isopropyl groups are ordered in 2 , and the most acute torsion angles are $\mathrm{C} 3-\mathrm{C} 4-\mathrm{C} 7-\mathrm{C} 8=51.9(5)^{\circ}$ and $\mathrm{C} 17-\mathrm{C} 16-\mathrm{C} 19-\mathrm{C} 20=$ $-28.6(5)^{\circ}$. In the structure (Figure $3 \mathrm{~b}$ ), chains of $\mathrm{N}-\mathrm{H} . . . \mathrm{O}$ hydrogen-bonded molecules are formed along [010].

The two molecules alternate along the chain leading to the formation of two hydrogen bonding interactions (with the geometries N1-H1 .. O2 $=149.8^{\circ}, \mathrm{N} 1 \ldots \mathrm{O} 2=2.872(4) \AA$ and N3-H3A... O1 = $\left.134.5^{\circ}, \mathrm{N} 3 \ldots \mathrm{O} 1=2.799(4) \AA\right)$. Although not identical, the chains of the hydrogen-bonded molecules are similar in both $\mathbf{1}$ and $\mathbf{2}$ as indicated by the overlay plot in Figure 4.

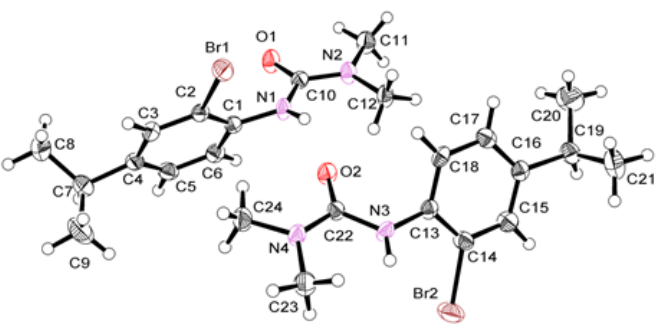

(a)

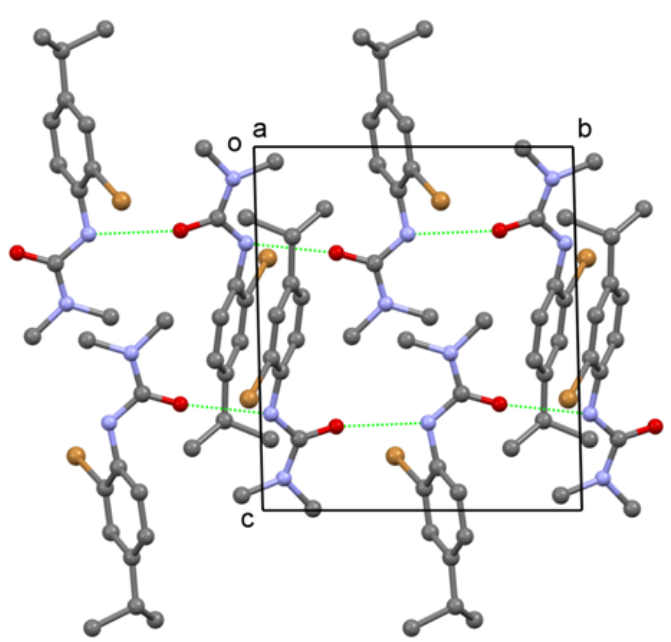

(b)

Figure 3. (a) An ortep representation of the asymmetric unit of $\mathbf{2}$ showing the two molecules in the asymmetric unit; (b) Crystal packing viewed down the $a$ axis with the hydrogen atoms omitted for clarity. Hydrogen bonds are shown as dashed lines.

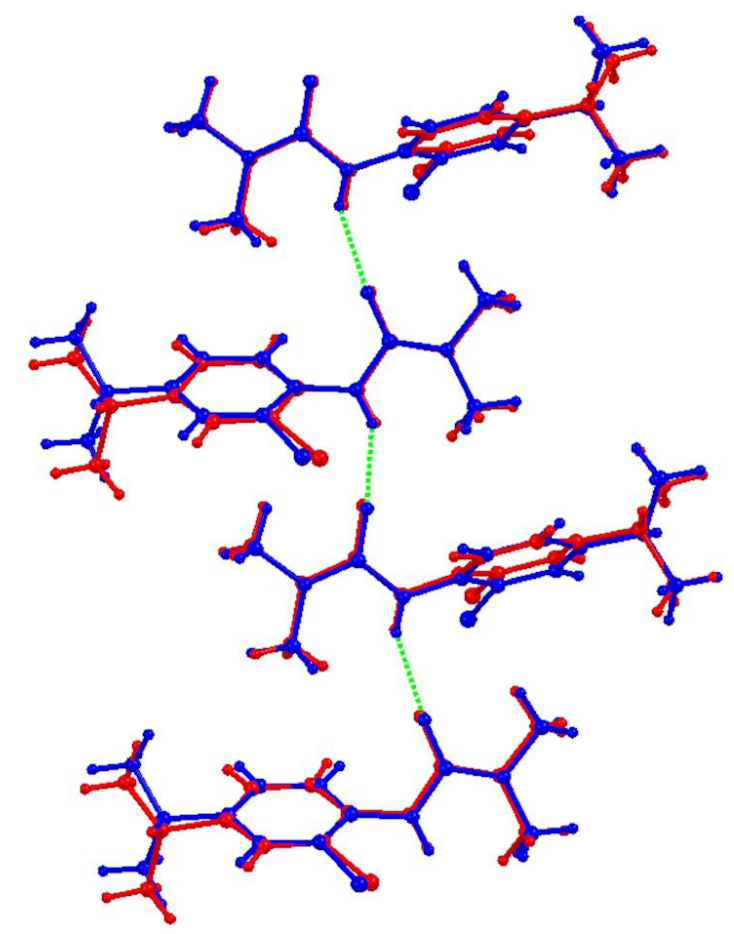

Figure 4. An overlay of the hydrogen bonded chains from $\mathbf{1}_{\mathbf{L T}}$ (red) and $\mathbf{2}$ (blue). The minor disorder component in $\mathbf{1}$ has been omitted for clarity. 
On cooling the crystal from $296 \mathrm{~K}$, the structure transforms from a monoclinic to a triclinic crystal system, retaining a similar unit cell volume. The single molecule in the asymmetric unit of the monoclinic structure above the phase transition temperature has a disordered isopropyl group. The refined ratios of the disordered components of the isopropyl group at $296 \mathrm{~K}$ and $200 \mathrm{~K}$ are $0.645(15) / 0.355(15)$ and $0.725(16) / 0.275(16)$, respectively. The values are significantly different from the 1:1 ratio of the two conformations of the independent molecules observed in the ordered structure of $\mathbf{2}$. This suggests that the isopropyl group has some rotational freedom about the $\mathrm{C}-\mathrm{C}\left(\mathrm{CH}_{3}\right)_{2}$ bond. Disorder in isopropyl groups is common, but significant isopropyl rotation is expected to occur only in exceptional circumstances as, for example, observed in 1-(benzoyl)-3-((5'-isopropyl-2'-methylphenoxy)acetamino) thiourea [30].

\section{Experimental Section}

\subsection{General}

Melting point determination was performed on a Gallenkamp melting point apparatus. ${ }^{1} \mathrm{H}(400 \mathrm{MHz})$ and ${ }^{13} \mathrm{C}$ NMR $(100 \mathrm{MHz})$ spectra were recorded on a Bruker AV400 spectrometer. The chemical ionization (ammonia) mass spectrum was recorded on a Quattro II spectrometer at $50 \mathrm{eV}$. Accurate mass data were recorded on a MAT900 instrument.

\subsection{Synthesis of 3-(2-Bromo-4-(1-methylethyl)phenyl)-1,1-dimethylurea}

The title compound was produced from reaction of 2-bromo-4-(1-methylethyl)aniline (10 mmol) and dimethylcarbamoyl chloride $(11 \mathrm{mmol})$ in dichloromethane $(40 \mathrm{~mL})$ under reflux for $1 \mathrm{~h}$ in the presence of excess triethylamine $(15 \mathrm{mmol})$. On cooling, the solvent was removed under reduced pressure and the residue obtained was purified by crystallization from diethyl ether to give the title compound as colourless crystals. Mp 93-94 ${ }^{\circ} \mathrm{C} .{ }^{1} \mathrm{H}$ NMR $\left(\mathrm{CDCl}_{3}, 400 \mathrm{MHz}\right) \delta 8.08(\mathrm{~d}, J=7.3 \mathrm{~Hz}, 1 \mathrm{H}$, H-6), 7.33 (s, 1 H, H-3), 7.15 (d, J = 7.3 Hz, 1 H, H-5), 6.91 (br s, exch., $1 \mathrm{H}, \mathrm{NH}), 3.06$ (s, $\left.6 \mathrm{H}, \mathrm{N}\left(\mathrm{CH}_{3}\right)_{2}\right)$, 2.83 (septet, $J=7.2 \mathrm{~Hz}, 1 \mathrm{H}, \mathrm{CH}), 1.20\left(\mathrm{~d}, J=7.2 \mathrm{~Hz}, 6 \mathrm{H}, \mathrm{CH}\left(\mathrm{CH}_{3}\right)_{2}\right) .{ }^{13} \mathrm{C} \mathrm{NMR}\left(\mathrm{CDCl}_{3}, 100 \mathrm{MHz}\right) \delta$ 156.1 (s, C=O), 135.2 (s, C-4), 133.3 (s, C-1), 131.3 (d, C-3), 125.0 (d, C-5), 123.9 (s, C-6), 121.4 (d, C-2), 35.1 (q, $\left.\mathrm{N}\left(\mathrm{CH}_{3}\right)_{2}\right), 31.8(\mathrm{~d}, \mathrm{CH}) ; 24.0\left(\mathrm{q}, \mathrm{CH}\left(\mathrm{CH}_{3}\right)_{2}\right)$. EI-MS: $\mathrm{m} / \mathrm{z}(\%) 284\left(\mathrm{M}^{+}, 5\right), 177$ (11), 72 (100); CI-MS: $m / z(\%) 302\left(\left[\mathrm{M}+\mathrm{NH}_{4}\right]^{+}, 2\right), 285\left(\mathrm{MH}^{+}, 100\right), 177$ (22), 72 (100). HRMS (CI): calculated for $\mathrm{C}_{12} \mathrm{H}_{17} \mathrm{BrN}_{2} \mathrm{O}\left(\mathrm{MH}^{+}\right)$: 285.0603; found: 285.0603. IR (KBr) $v_{\max } 3292,2990,2496,1690,1580,1520$, $1480 \mathrm{~cm}^{-1}$. Anal. Calcd for $\mathrm{C}_{12} \mathrm{H}_{17} \mathrm{BrN}_{2} \mathrm{O}: \mathrm{C}, 50.54 ; \mathrm{H}, 5.96 ; \mathrm{N}, 9.82$. Found: $\mathrm{C}, 50.34 ; \mathrm{H}, 5.83 ; \mathrm{N}, 9.97 \%$.

\subsection{Structure Determination}

Single-crystal XRD data were collected on an Agilent SuperNova Dual Atlas diffractometer with a mirror monochromator [Mo $(\lambda=0.7107 \AA)]$ equipped with a Cryosystems cooling apparatus. The crystal structures were solved and refined using SHELX [38]. Non-hydrogen atoms were refined with anisotropic displacement parameters. All hydrogen atoms were placed in calculated positions and refined using a riding model. Methyl $\mathrm{C}-\mathrm{H}$ bonds were fixed at $0.98 \mathrm{~A}$, with displacement parameters 1.5 times $\mathrm{Ueq}(\mathrm{C})$, and were allowed to spin about the $\mathrm{C}-\mathrm{C}$ bond. Aromatic $\mathrm{C}-\mathrm{H}$ distances were set to $0.95 \mathrm{~A}$ and their $\mathrm{U}$ (iso) set to 1.2 times the Ueq for the atoms to which they are bonded. The disordered isopropyl group in $\mathbf{1}$ was refined with two components and restrained geometry. Crystal data, data collection and structure refinement details are summarized in Table 1. CCDC 1532132-1532134 contain the supplementary crystallographic data for this paper. These data can be obtained free of charge via http:/ / www.ccdc.cam.ac.uk/conts/retrieving.html (or from the CCDC, 12 Union Road, Cambridge CB2 1EZ, UK; Fax: +44 1223 336033; E-mail: deposit@ccdc.cam.ac.uk.

\section{Conclusions}

3-(2-Bromo-4-(1-methylethyl)phenyl)-1,1-dimethylurea was synthesized and its structure was established at $296 \mathrm{~K}, 200 \mathrm{~K}$ and $140 \mathrm{~K}$. A phase transformation was observed at $170-180 \mathrm{~K}$ on cooling 
the crystal. The structure transforms from a monoclinic to a triclinic crystal system in a single-crystal to single-crystal manner, retaining a similar unit cell volume. The transformation is reversible on warming. The isopropyl group is disordered above the phase transition temperature but is ordered below the transition temperature.

Acknowledgments: The project was supported by King Saud University, Deanship of Scientific Research, Research Chair and Cardiff University.

Author Contributions: Gamal A. El-Hiti performed the synthesis of the title compound and established its structure by NMR, mass spectroscopy and analytical data. Benson M. Kariuki carried out the X-ray structure determination and thermal phase transformation of the title compound. Both authors wrote the paper.

Conflicts of Interest: The authors declare no conflict of interest.

\section{References}

1. Kocyigit-Kaymakcioglu, B.; Celen, A.O.; Tabanca, N.; Ali, A.; Khan, S.I.; Khan, I.A.; Wedge, D.E. Synthesis and biological activity of substituted urea and thiourea derivatives containing 1,2,4-triazole moieties. Molecules 2013, 18, 3562-3576. [CrossRef] [PubMed]

2. Khan, K.M.; Saeed, S.; Ali, M.; Gohar, M.; Zahid, J.; Khan, A.; Perveen, S.; Choudhary, M.I. Unsymmetrically disubstituted urea derivatives: A potent class of antiglycating agents. Bioorg. Med. Chem. 2009, 17, 2447-2451. [CrossRef] [PubMed]

3. Dos Santos, L.; Lima, L.A.; Cechinel-Filho, V.; Correa, R.; Buzzi, F.d.C.; Nunes, R.J. Synthesis of new 1-phenyl-3-\{4-[(2E)-3-phenylprop-2-enoyl]phenyl\}-thiourea and urea derivatives with anti-nociceptive activity. Bioorg. Med. Chem. 2008, 16, 8526-8534. [CrossRef] [PubMed]

4. Kozikowski, A.P.; Zhang, J.; Nan, F.; Petukhov, P.A.; Grajkowska, E.; Wroblewski, J.T.; Yamamoto, T.; Bzdega, T.; Wroblewska, B.; Neale, J.H. Synthesis of urea-based inhibitors as active site probes of glutamate carboxypeptidase II: Efficacy as analgesic agents. J. Med. Chem. 2004, 47, 1729-1738. [CrossRef] [PubMed]

5. Hemantha, H.P.; Chennakrishnareddy, G.; Vishwanatha, T.M.; Sureshbabu, V.V. One-pot synthesis of ureido peptides and urea-tethered glycosylated amino acids employing Deoxo-Fluor and TMSN3. Synlett 2009, 407-410. [CrossRef]

6. Carnaroglio, D.; Martina, K.; Palmisano, G.; Penoni, A.; Domini, C.; Cravotto, G. One-pot sequential synthesis of isocyanates and urea derivatives via a microwave-assisted Staudinger-aza-Wittig reaction. Beilstein J. Org. Chem. 2013, 9, 2378-2386. [CrossRef] [PubMed]

7. Han, C.; Porco, J.A., Jr. Synthesis of carbamates and ureas using $\mathrm{Zr}(\mathrm{IV})$-catalyzed exchange processes. Org. Lett. 2007, 9, 1517-1520. [CrossRef] [PubMed]

8. Wu, C.; Cheng, H.; Liu, R.; Wang, Q.; Hao, Y.; Yu, Y.; Zhao, F. Synthesis of urea derivatives from amines and $\mathrm{CO}_{2}$ in the absence of catalyst and solvent. Green Chem. 2010, 12, 1811-1816. [CrossRef]

9. Marinescu, L.; Thinggaard, J.; Thomsen, I.B.; Bols, M. Radical azidonation of aldehydes. J. Org. Chem. 2003, 68, 9453-9455. [CrossRef] [PubMed]

10. Padiya, K.J.; Gavade, S.; Kardile, B.; Tiwari, M.; Bajare, S.; Mane, M.; Gaware, V.; Varghese, S.; Harel, D.; Kurhade, S. Unprecedented "in water" imidazole carbonylation: paradigm shift for preparation of urea and carbamate. Org. Lett. 2012, 14, 2814-2817. [CrossRef] [PubMed]

11. Vasantha, B.; Hemantha, H.P.; Sureshbabu, V.V. 1-Propanephosphonic acid cyclic anhydride (T3P) as an efficient promoter for the Lossen rearrangement: Application to the synthesis of urea and carbamate derivatives. Synthesis 2010, 2990-2996. [CrossRef]

12. Dube, P.; Nathel, N.F.F.; Vetelino, M.; Couturier, M.; Aboussafy, C.L.; Pichette, S.; Jorgensen, M.L.; Hardink, M. Carbonyldiimidazole-mediated Lossen rearrangement. Org. Lett. 2009, 11, 5622-5625. [CrossRef] [PubMed]

13. Paz, J.; Perez-Balado, C.; Iglesias, B.; Munoz, L. Different reactivity of hydroxylamine with carbamoyl azides and carbamoyl cyanides: Synthesis of hydroxyureas and carbamoyl amidoximes. J. Org. Chem. 2010, 75, 8039-8047. [CrossRef] [PubMed]

14. Spyropoulos, C.; Kokotos, C.G. One-pot synthesis of ureas from Boc-protected amines. J. Org. Chem. 2014, 79, 4477-4483. [CrossRef] [PubMed] 
15. Artuso, E.; Degani, I.; Fochi, R.; Magistris, C. Preparation of mono-, di-, and trisubstituted ureas by carbonylation of aliphatic amines with S,S-dimethyl dithiocarbonate. Synthesis 2007, 3497-3506. [CrossRef]

16. Mizuno, T.; Nakai, T.; Mihara, M. Synthesis of unsymmetrical ureas by sulfur-assisted carbonylation with carbon monoxide and oxidation with molecular oxygen under mild conditions. Synthesis 2009, 2492-2496. [CrossRef]

17. Kim, S.H.; Hong, S.H. Ruthenium-catalyzed urea synthesis using methanol as the C1 source. Org. Lett. 2016, 18, 212-215. [CrossRef] [PubMed]

18. Thalluri, K.; Manne, S.R.; Dev, D.; Mandal, B. Ethyl 2-cyano-2-(4-nitrophenylsulfonyloxyimino) acetate-mediated Lossen rearrangement: Single-pot racemization-free synthesis of hydroxamic acids and ureas from carboxylic acids. J. Org. Chem. 2014, 79, 3765-3775. [CrossRef] [PubMed]

19. Vinogradova, E.V.; Fors, B.P.; Buchwald, S.L. Palladium-catalyzed cross-coupling of aryl chlorides and triflates with sodium cyanate: A practical synthesis of unsymmetrical ureas. J. Am. Chem. Soc. 2012, 134, 11132-11135. [CrossRef] [PubMed]

20. Le, H.V.; Ganem, B. Trifluoroacetic anhydride-catalyzed oxidation of isonitriles by DMSO: A rapid, convenient synthesis of isocyanates. Org. Lett. 2011, 13, 2584-2585. [CrossRef] [PubMed]

21. Smith, K.; El-Hiti, G.A.; Alshammari, M.B. Directed lithiation of $N^{\prime}$-[2-(4-methoxyphenyl)ethyl]-N,Ndimethylurea and tert-butyl [2-(4-methoxyphenyl)ethyl]carbamate. Synthesis 2014, 46, 394-402. [CrossRef]

22. Smith, K.; El-Hiti, G.A.; Alshammari, M.B.; Fekri, A. Control of site of lithiation of 3-(aminomethyl)pyridine derivatives. Synthesis 2013, 45, 3426-3434. [CrossRef]

23. Smith, K.; El-Hiti, G.A.; Alshammari, M.B. Lithiation and substitution of $N^{\prime}-(\omega$-phenylalkyl)- $N, N-$ dimethylureas. Synthesis 2012, 44, 2013-2022. [CrossRef]

24. Smith, K.; El-Hiti, G.A.; Alshammari, M.B. Variation in the site of lithiation of 2-(2-methylphenyl)ethanamine derivatives. J. Org. Chem. 2012, 77, 11210-11215. [CrossRef] [PubMed]

25. Smith, K.; El-Hiti, G.A.; Hegazy, A.S. Lateral lithiation of $N^{\prime}-(2$-methylbenzyl)- $N, N$-dimethylurea and N-(2-methylbenzyl)pivalamide: Synthesis of tetrahydroisoquinolines. Synthesis 2010, 1371-1380. [CrossRef]

26. Taylor, R.G.D.; Yeo, B.R.; Hallett, A.J.; Kariuki, B.M.; Pope, S.J.A. An organometallic complex revealing an unexpected, reversible, temperature induced SC-SC transformation. CrystEngComm 2014, 16, 4641-4652. [CrossRef]

27. Khoj, M.A.; Hughes, C.E.; Harris, K.D.M.; Kariuki, B.M. Polymorphism in a trans-cinnamic acid derivative exhibiting two distinct $\beta$-type phases: Structural properties, [2 + 2] photodimerization reactions, and polymorphic phase transition behavior. Cryst. Growth Des. 2013, 13, 4110-4117. [CrossRef]

28. Yates, J.L.R.; Sparkes, H.A. 4-Bromo-trans-cinnamic acid: Structural characterisation and crystallographic investigation into the solid state [2+2] cycloaddition reaction and temperature induced phase transition. CrystEngComm 2013, 15, 3547-3553. [CrossRef]

29. Palmer, B.A.; Kariuki, B.M.; Morte-Rodenas, A.; Harris, K.D.M. Structural rationalization of the phase transition behavior in a solid organic inclusion compound: bromocyclohexane/thiourea. Cryst. Growth Des. 2012, 12, 577-582. [CrossRef]

30. Pete, U.D.; Dikundwar, A.G.; Sharma, V.M.; Gejji, S.P.; Bendre, R.S.; Guru Row, T.N. Partial rotation of the isopropyl group in the solid state: Single-crystal-to-single-crystal phase transformation in a carvacrol derivative. CrystEngComm 2015, 17, 7482-7485. [CrossRef]

31. Rubin-Preminger, J.M.; Bernstein, J.; Harris, R.K.; Evans, I.R.; Ghi, P.Y. [R,S]-ethambutol dihydrochloride: Variable-temperature studies of a dimorphic system with very similar packing. J. Pharm. Sci. 2004, 93, 2810-2819. [CrossRef] [PubMed]

32. Sorensen, A.M.; Simonsen, O. The structures of $(R, S)-2,2^{\prime}$-(1,2-ethanediyldiimino)bis-1-butanol dihydroehlodde at 295 and 333 K. A reversible phase transition. Acta Crystallogr. C 1989, 45, 4. [CrossRef]

33. Das, D.; Engel, E.; Barbour, L.J. Reversible single-crystal to single-crystal polymorphic phase transformation of an organic crystal. Chem. Commun. (Cambridge UK) 2010, 46, 1676-1678. [CrossRef] [PubMed]

34. Hu, C.; Englert, U. Crystal-to-crystal transformation from a chain polymer to a two-dimensional network at low temperatures. Angew. Chem. Int. Ed. 2005, 44, 2281-2283. [CrossRef] [PubMed]

35. Zhang, J.-P.; Lin, Y.-Y.; Zhang, W.-X.; Chen, X.-M. Temperature- or guest-induced drastic single-crystal-to-single-crystal transformations of a nanoporous coordination polymer. J. Am. Chem. Soc. 2005, 127, 14162-14163. [CrossRef] [PubMed] 
36. Dunitz, J.D. Phase transitions in molecular crystals from a chemical viewpoint. Pure Appl. Chem. 1991, 63, 177-185. [CrossRef]

37. Meijer, M.D.; Gebbink, R.J.M.K.; van Koten, G. Solid-gas interactions between small gaseous molecules and transition metals in the solid state. Toward sensor applications. Perspect. Supramol. Chem. 2003, 7, 375-386.

38. Sheldrick, G.M. A short history of SHELX. Acta Crystallogr. Sect. A Found. Crystallogr. 2008, 64, $112-122$. [CrossRef] [PubMed] 